\title{
VIOLÊNCIA INTRAFAMILIAR CONTRA CRIANÇAS E ADOLESCENTES: INTERCONTEXTUALIDADE DE SIGNIFICADOS VERBAIS E IMAGÉTICOS
}

\author{
Intrafamilial Violence towards Children \\ and Teenagers: Intercontextuality \\ of Verbal and Visual Significations \\ Violencia intrafamiliar contra niños \\ y adolescentes: intercontextualidad \\ de significados verbales e imagéticos
}

Johwyson da Silva Rodrigues*

Universidade Federal do Pará, Faculdade de Letras Estrangeiras Modernas, Belém, PA, Brasil

\begin{abstract}
Resumo: Este trabalho objetiva investigar traços da violência intrafamiliar contra crianças e adolescentes presentes nos significados verbal e visual do jogo digital The Binding of Isaac (2011), ressaltando, assim, sua multimodalidade. Como aporte teórico-metodológico, foram utilizados fundamentos da Análise Crítica do Discurso (ACD) e da Gramática do Design Visual (GDV) para detectar possíveis processos visuais, intertextualidades e interdiscursividades que pudessem revelar pistas da violência intrafamiliar contra crianças e adolescentes como prática social presente no jogo. Os resultados obtidos confirmam que a personagem principal possui todas as características comuns às vítimas que sofrem desse tipo de abuso. Concluiu-se, também, que o jogo em questão, como um veículo de comunicação, possui a função, para quem o joga, de apresentar e alertar sobre o tema. Espera-se que este estudo possa contribuir ainda mais para a consolidação da Semiótica Social, com o apoio da ACD como um aporte teórico-metodológico eficiente na investigação de práticas sociais.
\end{abstract}

Palavras-chave: Violência intrafamiliar. Análise Crítica do Discurso. Gramática do Design Visual.

\begin{abstract}
This paper aims to investigate signs of intrafamilial violence towards children and teenagers found in verbal and visual meanings in the digital game The Binding of Isaac (2011), drawing attention to its multimodality. The research's theoretical-methodological framework brought some specific concepts from Critical Discourse Analysis (CDA) and the Grammar of Visual Design (GVD), in order to detect possible visual processes, intertextualities, as well as interdiscursivities that could reveal signs of intrafamilial violence against children and teenagers as a social practice in the game. The results confirmed that the main character has all the features usually found in victims who experienced such kind of abuse. We conclude that the game acts as communication vehicle because it possesses the function of introducing and alerting players about such theme. With support of CDA, we hope this research can further contribute to the Social Semiotics consolidation, as an effective framework to investigate social practices.
\end{abstract}

Keywords: Intrafamilial Violence. Critical Discourse Analysis. Grammar of Visual Design.

Resumen: Este trabajo tiene el objetivo de investigar rastros de violencia intrafamiliar contra niños y adolescentes presentes en significados verbales y visuales del juego digital The Binding of Isaac (2011), despegando, así, su multimodalidad. Como contribución teórico-metodológica, fueron utilizados fundamentos del Análisis Crítico del Discurso (ACD) y de la Gramática del Design Visual (GDV) para detectar posibles procesos visuales, intertextualidades e inter-discursividades que pudiesen aclarar rastros de violencia intrafamiliar contra niños y adolescentes como práctica social presente en el juego. Los resultados obtenidos comprueban que el personaje principal posee todas las características comunes de víctimas que sufren ese tipo de maltrato. También se concluye que el juego em cuestión, como vehículo de

\footnotetext{
* Doutor em Estudos da Tradução. Docente do Instituto de Letras e Comunicação da UFPA. ORCID: https://orcid.org/0000-0001-6479-1444. E-mail: johwyson@yahoo.com.
}

RODRIGUES, Johwyson da Silva. Violência intrafamiliar contra crianças e adolescentes: intercontextualidade de significados verbais e imagéticos. Linguagem em (Dis)curso - LemD, Tubarão, SC, v. 20, n. 3, p. 431-450, set./dez. 2020. 
comunicación, posee función, para quién lo juega, de presentar y alertar sobre el tema. Se espera que el estudio pueda contribuir aún más para la consolidación de la Semiótica Social, con el apoyo del ACD como contribución teórico-metodológico eficiente en la investigación de prácticas sociales.

Palabras clave: Violencia intrafamiliar. Análisis Crítico del Discurso. Gramática del Design Visual.

\section{INTRODUÇÃO}

Nas últimas décadas, o tema da violência intrafamiliar contra crianças e adolescentes (VICCA) tem sido uma discussão constante em pautas que envolvem saúde pública, políticas públicas, educação, entre outras esferas. Desde a criação do artigo 227 , da Constituição Federal Brasileira (1988), que dispõe sobre os deveres da família quanto a assegurar direitos básicos à criança e ao adolescente, assim como resguardá-los de quaisquer constrangimentos ou violências, o tema ganha força e importância, seja pela implementação de leis, como o Estatuto da Criança e do Adolescente (1990), seja por meio de campanhas publicitárias nacionais de combate a esse tipo de violência.

Conforme Moralis et al. (2016, p. 1646), a VICCA diz respeito a "toda ação ou omissão que possa prejudicar o bem-estar, a integridade física, psicológica ou a liberdade e o direito ao pleno desenvolvimento de um membro da família". O agressor, nesse tipo de situação, pode ser um membro da família ou alguém que assume esta função. Os efeitos provocados nas vítimas, geralmente crianças e adolescentes tidos como vulneráveis, podem ser de ordem física, psicológica, moral, sexual ou financeira, envolvendo também a negligência e o abandono. Nas palavras de Ramos e Silva (2011, p. 137), tais efeitos podem ter "prejuízos a curto, médio e longo prazos, tanto de ordem física como psicossocial, que podem ser devastadores, já que as experiências vividas na infância refletem na vida adulta".

Com base em Garbarino et al. (1986), Abranches e Assis (2011) destacam cinco ações parentais consideradas tóxicas, as quais podem auxiliar na detecção de abusos: rejeitar, quando os pais recusam-se a aceitar a legitimidade da criança e suas necessidades; isolar, quando os pais impedem a criança de ter contato com pessoas e locais de convivência social, levando-a a acreditar que está sozinha no mundo; aterrorizar, quando a criança, após sofrer ataques verbais constantes, passa a perceber o mundo como um lugar hostil; ignorar, quando a criança é privada de estímulos que possam levá-la a desenvolver suas capacidades emocionais e intelectuais; e corromper, quando a criança é estimulada a ter comportamentos negativos e antissociais. Ao citarem autores como O'Hagan (1995) e Brassard et al. (1993), as autoras também afirmam que os pais considerados agressores geralmente incutem na criança crenças que giram em torno do quão inferior ela é, que não é amada, nem querida e que seu valor está atrelado a uma relação de necessidade entre ela e as outras pessoas.

O jogo digital The Binding of Isaac (2011), objeto de estudo, chama a atenção pela sua jogabilidade, proporcionando momentos de diversão por meio, por exemplo, da derrota de um inimigo monstruoso ou pela obtenção de itens poderosos. Sua trama certamente pode causar estranheza ao eleger como personagem principal a figura sofrida e indefesa de uma criança chamada Isaac, que, conforme a análise realizada neste 
trabalho, é vítima da violência intrafamiliar infligida por sua mãe. Segundo Otero (2017), o jogo é divertido e repleto de surpresas, tendo recebido nota nove no conceituado site de games IGN, do qual o autor é um dos seus editores. Por mais difícil que o jogo seja, fazendo com que o jogador morra várias vezes, cada reinício, segundo o autor, é uma chance para se descobrir coisas novas. O jogo é, ao mesmo tempo, engraçado e perturbador, acrescenta ele, dando àquele que o joga a motivação necessária para tentar destravar todos os seus vinte possíveis finais em forma de cutscenes $^{1}$.

Este estudo, portanto, tem como objetivo verificar como o jogo digital The Binding of Isaac (2011) constrói significados, seja por meio de recursos imagéticos ou verbais, destacando, assim, sua multimodalidade, que envolve a violência intrafamiliar sofrida pela personagem Isaac. Como apoio teórico optou-se, basicamente, pela utilização dos conceitos de intercontextualidade, de intertextualidade e interdiscursividade pertencentes à Análise Crítica do Discurso (ACD), além de conceitos provenientes da Gramática do Design Visual (GDV).

Este artigo encontra-se subdividido em cinco seções. As duas primeiras seções versam sobre os conceitos fundamentais que envolvem a ACD e a GDV, respectivamente; a terceira seção apresenta a sua metodologia; a quarta seção proporciona a análise e sua breve discussão; e, finalmente, na quinta seção, são dispostas as suas considerações finais.

\section{A ANÁLISE CRÍTICA DO DISCURSO}

A ACD, concebida por Fairclough (CHOULIARAKI e FAIRCLOUGH, 1999; FAIRCLOUGH, 2003, 2010, 2012), tem por objetivo analisar os fenômenos semióticos envolvidos nas estruturas e ações sociais, valendo-se da transdisciplinaridade com outras áreas do conhecimento. Dentre algumas pesquisas com base na ACD, podem ser citados o trabalho de Campos e Barros (2014), que analisam a ratificação de uma identidade marginalizada da mulher brasileira em uma propaganda audiovisual de 2010, com o propósito de homenagear o Dia Internacional da Mulher; e o trabalho de Oliveira e Pimenta (2016), que investiga como a publicação de anúncios de emprego com exigências fenotípicas e critérios comportamentais contribuiu para agravar a desigualdade social e econômica entre brancos e negros no Estado de São Paulo, início do século XX.

A Linguística Sistêmico-Funcional (HALLIDAY, 1989, 1994, 2004, 2014; FUZER; CABRAL, 2014), doravante LSF, na qual boa parte das teorias que compõem a ACD é ancorada, compreende língua e linguagem como parte integrante das práticas sociais. Para Heberle (2018), a LSF é uma importante ferramenta para se analisar textos e gêneros discursivos, tendo como objeto as mais variadas mídias e contextos sociais. Além disso, esta abordagem tem contribuído para os Estudos Linguísticos como um todo e, segundo a autora, para a área da Linguística Aplicada no que diz respeito às pesquisas sobre a linguagem em uso, práticas sociais, ensino de línguas e multiletramentos.

\footnotetext{
${ }^{1}$ Cutscenes, segundo Egenfeldt-Nielsem, Smith e Tosca (2008), são sequências narrativas em que o jogador tem pouco ou nenhum controle sobre a cena.
}

RODRIGUES, Johwyson da Silva. Violência intrafamiliar contra crianças e adolescentes: intercontextualidade de significados verbais e imagéticos. Linguagem em (Dis)curso - LemD, Tubarão, SC, v. 20, n. 3, p. 431-450, set./dez. 2020. 
Para a LSF, o texto é concebido não apenas como algo verbal, mas também gestual, visual, sonoro, etc., sendo melhor definido como um corpo funcional que realiza uma tarefa por meio de recursos semióticos em um dado contexto. Sua natureza é, portanto, tanto estrutural quanto semântica. O contexto é subdividido em contexto de cultura, voltado ao gênero, e contexto de situação, compreendido por meio de suas variáveis: campo, relações e modo. O campo está ligado à atividade realizada, sua natureza e seus propósitos comunicativos; as relações investigam as trocas de mensagens realizadas entre os participantes, assim como suas relações; e o modo está voltado às várias formas pelas quais a linguagem veicula a comunicação. Nessas variáveis são realizadas, respectivamente, as metafunções: ideacional, ligada às representações das experiências do mundo interior e exterior; interpessoal, referente às interações entre os sujeitos e aos papéis que eles desempenham; e textual, que diz respeito à estrutura do texto e a sua organização.

Com base nas metafunções da LSF, a ACD propõe as noções de gêneros, discursos e estilos, assim como seus tipos de significados: o acional, o representacional e o identificacional. Nesta perspectiva, os gêneros são tidos como modos de agir, os discursos são tidos como modos de representar e os estilos são tidos como modos de ser, refletindo os tipos de significados citados, respectivamente: o significado acional investiga o texto como modo de interação social, legitimando-o ou questionando-o; o significado representacional revela as representações do mundo tanto interno quanto externo; e o significado identificacional lida com as construções e manutenções de identidades. É importante salientar que tanto as metafunções da LSF quanto os tipos de significados da ACD ocorrem, no texto, de forma concomitante, sendo analisados separadamente apenas para efeito de investigação.

De um ponto de vista estratificado, pode-se dizer que, acima dos gêneros, discursos e estilos, encontra-se o sistema de ordens do discurso, o qual é tido como uma "articulação socialmente estruturada de práticas discursivas, incluindo gêneros, discursos e estilos, que constituem a faceta discursiva da ordem social de um campo social"'2 (CHOULIARAKI; FAIRCLOUGH, 1999, p. 114). Este sistema encontra-se relacionado ao que está semanticamente vigente e interligado em uma dada sociedade, nunca podendo ser compreendido como algo neutro, uma vez que está geralmente a serviço da dominância, como nas relações de poder, relações ideológicas, identitárias e institucionais.

Conforme Meurer (2007), a análise discursiva pode ocorrer por meio de três ângulos ou dimensões mutuamente complementares: o texto, as práticas discursivas e as práticas sociais. No âmbito textual, a análise pode levar em conta a léxico-gramática, a coesão e a estrutura textual, referentes à realização linguística manifestada pelo discurso. No âmbito das práticas discursivas, voltado à produção, distribuição e consumo de textos, é possível interpretá-lo em níveis voltados à coerência, intenções, intertextualidade e interdiscursividade, aproximando-se das práticas discursivas que o definem enquanto

\footnotetext{
2 Trecho original: "a socially structured articulation of discursive practices (including both genres and discourses) which constitutes the discursive facet of the social order of a social field" (CHOULIARAKI; FAIRCLOUGH, 1999, p. 114).

OBS: Todos os trechos traduzidos que aparecem em nota de rodapé foram realizados pelo autor da pesquisa, assim como todos os termos relacionados a itens e vilões do jogo.
} 
gênero e discurso. Por fim, na esfera voltada às práticas sociais, é possível investigar níveis voltados a ideologias e hegemonias, as quais podem ser reveladas por pistas ou marcas textuais.

$O$ gênero, para a $A C D$, que prefere o termo gênero discursivo e, mais especificamente o termo gênero situado $^{3}$, possui características acionais/relacionais e interacionais, pois é por meio dele que as pessoas agem e interagem socialmente. Ele tem suas propriedades voltadas tanto à materialidade textual, quanto às práticas discursivas e sociais, sendo norteado pelo sistema de ordens do discurso. Para Ramalho e Resende (2011, p. 60), "gêneros discursivos estão ligados a diferentes modos de ação/relação social estabelecidos discursivamente. Por isso, dizemos que os gêneros se referem a modos relativamente estáveis de (inter)ação por meio do discurso". Os gêneros discursivos e as relações de poder estão intimamente relacionados, já que, por meio do gênero, é possível controlar e legitimar tanto os discursos ideológicos quanto as representações de suas práticas sociais.

Uma característica importante do gênero discursivo é o seu potencial híbrido, já que, para a $\mathrm{ACD}$, um texto é tido como o resultado não de sua realização particular, mas da combinação de outros gêneros, ocorrendo por meio da mistura de formas ou de funções, como, por exemplo, no caso de um anúncio informativo que, na verdade, tem a função de vender um determinado produto. Nesse tipo de gênero, há sempre um gênero principal que envolve um subgênero.

A interdiscursividade, também chamada de intertextualidade constitutiva, é definida como sendo a hibridização de gêneros, discursos e estilos. Para Silva e Gonçalves (2017, p. 11), é por meio da interdiscursividade que "se notam as articulações do discurso com as práticas sociais e discursivas vinculadas a outras comunidades discursivas". A intertextualidade, por outro lado, também chamada de intertextualidade manifesta, é definida como "a presença de elementos reais pertencentes a outros textos, verificados dentro de um texto, como, por exemplo, as citações" (FAIRCLOUGH, 2003, p. 39). É por meio deste recurso que se pode verificar como textos, mais especificamente suas vozes, "lançam mão, incorporam, recontextualizam e dialogam com outros textos" 5 (FAIRCLOUGH, 2003, p. 17). Meurer (2004), com o objetivo de ampliar o leque teórico da ACD e da LSF, propõe o termo intercontextualidade, que ocorre quando dois ou mais contextos se inter-relacionam em uma dada prática social. Segundo o autor, "na intercontextualidade, um contexto é 'levado' para outro contexto e dá-se o compartilhamento de características de ambos, muitas vezes com o predomínio de um sobre o outro" (MEURER, 2004, p. 135).

Por meio dessa noção, é possível compreender os jogos digitais a partir de gêneros discursivos como os jogos de ação/aventura, jogos de mundo aberto, jogos de horror e sobrevivência, etc., assim como gêneros visivelmente mais híbridos, como os MMORPGs

\footnotetext{
${ }^{3}$ Para uma leitura mais aprofundada sobre as definições de gênero discursivo e gênero situado, checar Resende e Ramalho (2011).

4 Trecho original: "the presence of actual elements of other texts within a text - quotations" (FAIRCLOUGH, 2003, p. 39).

${ }^{5}$ Trecho original: "how texts draw upon, incorporate, recontextualize and dialogue with other texts" (FAIRCLOUGH, 2003, p. 17)
} 
(Massively Multiplayer Online Role-Playing Game), que compartilham o recurso da interatividade online entre seus jogadores, juntamente com a possibilidade de atribuição da interpretação de personagens. Em um nível intertextual, jogos como Tomb Raider (1996), por exemplo, apropriam-se de características comuns às mídias audiovisuais em seus cutscenes para realizar fugas mirabolantes que envolvem explosões e feitos quase impossíveis.

Em suma, pode-se afirmar que os jogos digitais, conforme Haag et al. (2005), além de conglomerarem simultaneamente vários gêneros, os trazem de modo convergente, isto é, seus gêneros dialogam entre si, fazendo com que se confirme a ideia de que jogos digitais são um hipergênero (MAINGUENEAU, 2010) ou um sistema de hipergenericidade. Este último termo, conforme Rezende (2018, p. 64), refere-se à característica desses gêneros que, quando unidos, revelam as "regularidades de um funcionamento discursivo que conflui para a manutenção de um dado posicionamento/identidade discursivo/a".

Após a breve explanação dos conceitos básicos que envolvem a $\mathrm{ACD}$, a próxima seção discorrerá sobre a fundamentação teórica pertencente à GDV.

\section{A GRAMÁTICA DO DESIGN VISUAL}

A partir dos fundamentos pertencentes à LSF, Kress e Van Leeuwen $(2001,2006)$ concebem a GDV, uma gramática geral do design visual que consiste de elementos e regras que envolvem uma forma específica de comunicação visual norteada pela cultura. Dentre alguns trabalhos que utilizam este aparato teórico, estão o de Resende e Gomes (2018), cujos resultados apontam, dentre outros fatores, para a naturalização da violência contra a população em situação de rua representada nos jornais web Correio Braziliense entre 2011 e 2013; e o de Leal (2018), que investiga representações semióticas no gênero reportagem contidas em duas revistas portuguesas.

A GDV vale-se das metafunções ideacional, interpessoal e textual da LSF, associando-as aos significados representacional, interativo e composicional, respectivamente. Os significados representacionais estão voltados às representações de mundo, os significados interativos lidam com as relações entre o produtor e o observador da imagem e os significados composicionais referem-se aos elementos que compõem o texto imagético. É importante salientar que, na GDV, os participantes que compõem uma dada imagem não atuam, como ocorre em uma conversa informal face-a-face, por exemplo. Assim, é preciso que o participante observador da imagem perceba a representação que envolve os participantes interativos, ou seja, os participantes que estão contidos na imagem.

Os significados representacionais subdividem-se em estruturas narrativas e estruturas conceituais. As estruturas narrativas, referentes às ações praticadas pelos participantes de uma imagem, subdividem-se em cinco processos: os acionais, os reacionais, os verbais, os mentais e os de conversão. Os processos acionais subdividemse em transacional, quando há mais de um participante, e não transacional, quando um vetor está direcionado a um participante. Esses processos assemelham-se, na gramática 
normativa, a verbos transitivos e intransitivos, respectivamente. Os processos reacionais são aqueles cujo foco está nas reações dos olhares dos participantes, podendo ocorrer de forma transacional e não transacional. Os processos verbais ocorrem por meio de balões que representam as falas dos participantes, ao passo que os processos mentais são realizados por balões que expressam os seus pensamentos. Finalmente, os processos de conversão são realizados por uma cadeia narrativa de processos transacionais.

As estruturas conceituais dizem respeito à essência atemporal de pessoas, objetos ou lugares e são subdivididas em processos classificacionais, analíticos e simbólicos. Nos processos classificacionais, o participante sofre algum tipo de organização taxonômica cujos itens são subordinados e superordenados. Nos processos analíticos, o foco está nas relações de uma parte com um todo. Nos processos simbólicos, os participantes são definidos por sua essência, podendo ocorrer por meio de processos atributivos ou sugestivos. Nos processos atributivos, o atributo normalmente qualifica o participante em termos identitários. Nos processos sugestivos, o participante é representado de forma subjetiva e abstrata.

Os significados interativos podem ser classificados sob quatro facetas: contato visual, distância social, perspectiva e modalidade. No contato visual, a presença ou ausência do contato visual do participante representado com o participante observador podem gerar imagens de demanda e de oferta, respectivamente. A distância social ocorre por meio de planos abertos, médios ou fechados (close-up), o que sugere diferentes níveis de interação entre os participantes. Quanto mais longe for a distância, mais afastada é a relação de interação social. A perspectiva diz respeito ao nível de poder que o participante interativo exerce sobre o participante observador. Ângulos frontais demonstram igualdade, ângulos oblíquos demonstram alheamento, ângulos verticais de cima para baixo demonstram a superioridade do participante interativo perante o participante observador e ângulos verticais de baixo para cima demonstram uma relação inversa. $\mathrm{Na}$ perspectiva, pode-se também observar a contextualização, que é a presença ou não de imagens de fundo, as quais podem ressaltar tipos hierárquicos. A modalidade, voltada aos diferentes graus de verdade que envolvem uma imagem, pode ser percebida por meio de marcadores, como saturação, modulação de cor, contextualização, representação, profundidade, iluminação e brilho. $\mathrm{O}$ aumento ou diminuição de tais marcadores incidem sobre o quão real uma imagem pode ser considerada, podendo ser classificada como naturalista, assemelhando-se ao mundo real, científico-metodológica, na qual predomina a eficiência da imagem, sensorial, relacionada ao prazer, às sensações e emoções, abstrata, relacionada ao que é tido como erudito.

Finalmente, os significados composicionais, os quais integram os significados representativos e interativos, possuem dimensões como o valor da informação, a saliência e o enquadramento. O valor da informação subdivide-se em dado e novo, em que o dado geralmente encontra-se disposto à esquerda e o novo à direita, ideal e real, em que o ideal encontra-se acima e o real encontra-se abaixo da imagem, e centro e margem, em que o centro da imagem é reservado a elementos essenciais e as margens são reservadas a elementos periféricos. A saliência, com função hierárquica e organizadora, está relacionada ao destaque de algum elemento por meio de cores, filtros, dimensões ou perspectivas. Por fim, o enquadramento diz respeito à delimitação de elementos, com função de unir ou separar por meio de linhas e bordas. 
A GDV tem contribuído para inúmeros trabalhos acadêmicos que versam sobre a multimodalidade, a qual, segundo Heberle e Morgado (2016, p. 62-63), "considera o uso de diferentes recursos semióticos na criação de sentidos" ${ }^{6}$, permitindo que a Análise do Discurso observe imagens de forma sistemática e crítica. A pesquisa de Dias e Gusso (2016), por exemplo, vale-se da GDV para analisar estratégias de polidez utilizadas em campanhas publicitárias publicadas pelo Ministério da Saúde.

A próxima seção apresentará a metodologia utilizada neste trabalho.

4 METODOLOGIA

Com o objetivo geral de investigar traços da VICCA presentes nas imagens e na tessitura discursivo-textual do jogo digital The Binding of Isaac (2011), o presente trabalho, com base na fundamentação teórica que advém da interface entre a ACD e a GDV, procurou observar como esta prática social relaciona-se ao texto e às suas práticas discursivas por meio de recursos visuais, da intertextualidade e da interdiscursividade. Para tanto, inicialmente, foram catalogadas as práticas discursivas mais relevantes no jogo, o que resultou em oito categorias: tecnologias de informação e comunicação, mídias audiovisuais, outros jogos digitais, aleatoriedade, biologia, suicídio, religiosidade e discursos do cotidiano familiar envolvendo sexualidade, bullying, repressão materna, ausência paterna e costumes e crendices na infância.

Inspirado no jogo clássico The Legend of Zelda (1986), The Binding of Isaac (2011) é um jogo digital independente, estilo plataforma, do tipo roguelike (gênero masmorra), criado por Edmund McMillen e Florian Himsl. Lançado originalmente para PC, MacOS e Linux, o jogo, atualmente, está presente em consoles como o Playstation 4, o Xbox One e o Nintento Switch. Jogos do tipo roguelike (2020), um subgênero dos jogos de RPG, são caracterizados por seu alto teor de fantasia, pela forma aleatória com que itens e inimigos aparecem na tela e pela morte constante de suas personagens. Com mais de três milhões de cópias vendidas, o jogo recebeu críticas bastante favoráveis e ganhou algumas atualizações como as $\mathrm{DLCs}^{7}$ Rebirth (2014), Afterbirth (2015) e Afterbirth+ (2017). Além do jogo digital, a franquia também recebeu um jogo de cartas intitulado The Binding of Isaac: Four Souls (2018). Segundo a classificação PEGI (Pan European Game Information), The Binding of Isaac (2011) é recomendado para maiores de 16 anos, uma vez que, apesar de gráficos que lembram um desenho animado, contém cenas de violência moderada e uso de drogas ilícitas.

No jogo, de acordo com o site The Binding of Isaac Rebirth Wiki (2019), há cerca de 196 itens que aparecem de forma randômica. Esses itens basicamente atribuem mais força à personagem. Com a chegada das suas atualizações, o número de itens aumentou para 547, assim como o número de inimigos, 197, e o número de chefões e mini-chefões, 72. Dessa forma, a listagem dos itens aqui mencionados, assim como seus monstros, está

\footnotetext{
${ }^{6}$ Trecho original: "considers the use of different semiotic resources in meaning-making [...] allows discourse analysts to observe images systematically and critically" (HEBERLE E MORGADO, 2016, p. 62-6).

7 O termo DLC significa downloadable content em inglês e refere-se ao posterior lançamento de complementos de jogos, comprados separadamente, disponíveis sob a forma de download em lojas virtuais de jogos digitais.
}

RODRIGUES, Johwyson da Silva. Violência intrafamiliar contra crianças e adolescentes: intercontextualidade de significados verbais e imagéticos. Linguagem em (Dis)curso - LemD, Tubarão, SC, v. 20, n. 3, p. 431-450, set./dez. 2020. 
longe de pretender dar conta de toda a relação que compõe o jogo. Ao assumir uma postura qualitativa, este trabalho pretende apenas aferir, por meio de alguns itens e monstros, as práticas discursivas mais relevantes presentes no jogo.

A trama do jogo, assim como o seu título, é declaradamente inspirada na passagem bíblica do sacrifício de Isaque, na qual a fé de Abraão é posta à prova após ouvir a voz de Deus ordenando o sacrifício de seu filho Isaque. $O$ enredo do jogo diverge sutilmente da passagem bíblica ao eleger a mãe de Isaac que, após ouvir uma voz ordenando a morte do filho, investe contra ele, munida de uma faca. Isaac, desesperado, encontra abrigo em um porão abaixo da casa e é ali que o jogo ocorre. Suas armas iniciais são suas lágrimas, as quais ele atira contra insetos e os mais variados monstros. Isaac é a personagem principal do jogo, mas, à medida em que se progride, outras personagens, itens e salas vão sendo liberados, como as personagens Magdalene, Cain, Judas ou Azazel, e os inimigos Mega Satan, Hush e Delirium.

Como dito anteriormente, para a LSF, o contexto de cultura diz respeito a questões que envolvem o gênero. O contexto de situação, por sua vez, lida com a situação específica em que um texto ocorre. Dessa forma, todas as características aqui apresentadas podem ser reconhecidas como o contexto de cultura no qual o jogo se insere.

A próxima seção, que também traz a análise, iniciará com a breve descrição do seu contexto de situação.

\section{A ANÁLISE}

O contexto de situação do jogo The Binding of Isaac (2011), no que toca ao seu campo, por meio do cutscene inicial, o qual é realizado por imagens em forma de desenho animado e um narrador, apresenta a família de Isaac, composta apenas por ele e sua mãe. Os dois moram em uma pequena casa. Isaac parece ser um garoto alegre que cria desenhos em uma folha de papel, enquanto sua mãe assiste à programação cristã na TV. Tudo parece tranquilo até o dia em que a mãe de Isaac ouve uma voz, provavelmente vinda do céu, dizendo que a alma de Isaac foi corrompida e que ele precisa ser salvo. Sua mãe, então, remove todos os pertences de Isaac que parecem ser maléficos, incluindo seu videogame portátil e as roupas que ele veste. Pela segunda vez, a mãe de Isaac ouve a voz que diz que ele ainda está corrompido. Como consequência, Isaac é trancado em seu quarto para que fique a salvo dos males do mundo. Em uma terceira vez, a voz ordena, como prova de amor e devoção, que Isaac seja sacrificado. Armada com uma faca, a mãe se dirige para o quarto do filho que, ao perceber suas intenções, esconde-se no porão da casa.

No que concerne às relações, a trama do jogo envolve, basicamente, a personagem Isaac que, apesar das variações de personagens com as quais se pode jogar, estas parecem estar atreladas à sua figura, já que o cutscene inicial refere-se apenas a ele. Além de Isaac, nota-se que sua mãe também possui um papel de destaque, quer seja no cutscene inicial, nos cutscenes que ocorrem entre as fases do jogo ou durante o próprio jogo, por meio de itens e monstros que fazem menção direta a ela, como, por exemplo, os itens Mom's bra (Sutiã da mãe), Mom's lipstick (Batom da mãe) ou os monstros Mom (Mãe) e Mom's heart (Coração da mãe). 
No que diz respeito ao modo, o jogo apresenta vários recursos que veiculam significados, como os visuais, voltados à imagem; os acionais, voltados ao gameplay $^{8}$; os sonoros, voltados aos sons e à trilha sonora; e os verbais, contidos nos cutscenes e nos nomes de itens e monstros que surgem ao longo do jogo. Dentre estes, apenas os significados verbais e imagéticos fazem parte da análise aqui realizada.

A figura 1 apresenta a imagem utilizada pela plataforma Steam, um software de compra de jogos digitais, na veiculação do jogo.

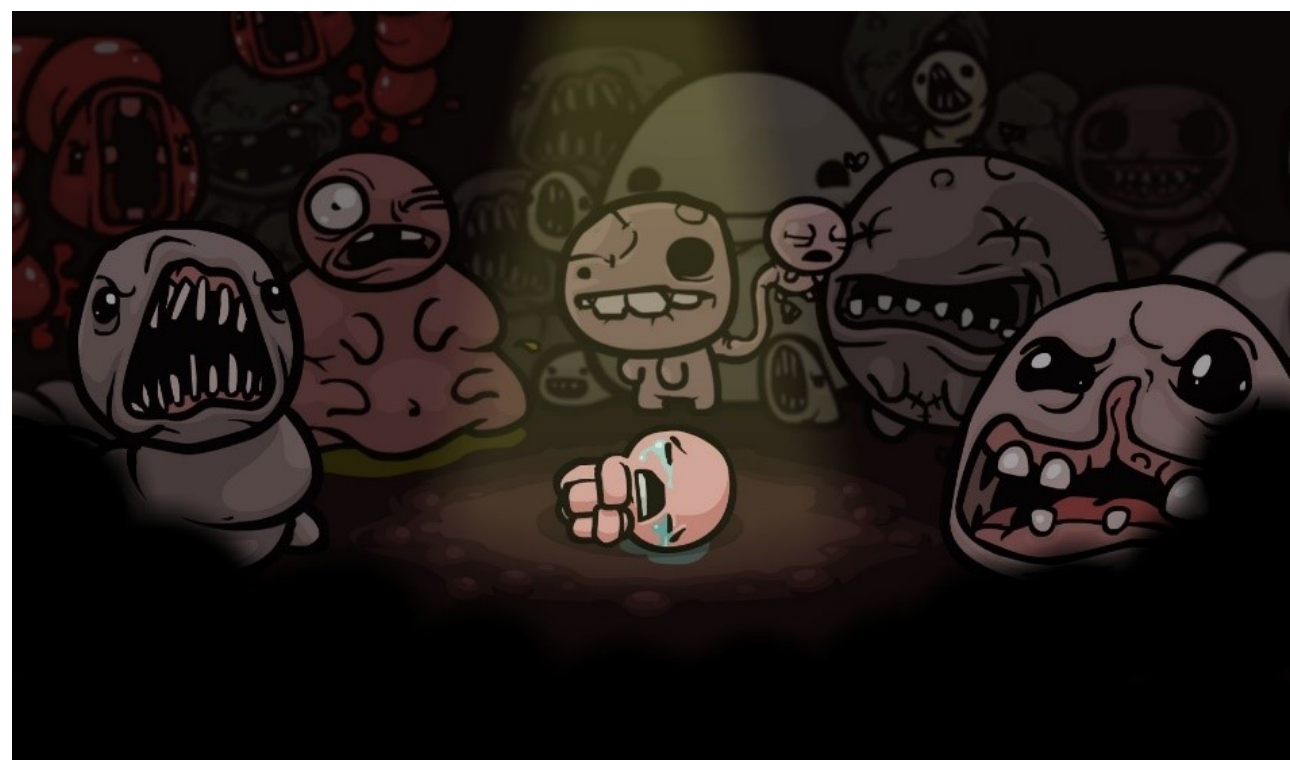

Figura 1 - Cartaz do jogo The Binding of Isaac (2011)

Fonte: https://steamcdn-

a.akamaihd.net/steam/apps/113200/ss_57c7fb142d6b8f7d38ab62d9f39a055a5b2d4c4c.1920x1080.jpg?t=1447354527

Por meio da figura, nota-se que Isaac, ao centro e destacado pela saliência da iluminação, encontra-se encolhido, chorando e aparentando visível desconforto e vulnerabilidade. A posição fetal em que se encontra, que alude à posição com que bebês ficam no ventre das mães, tem a função de demonstrar que o ambiente em que ele está é inóspito e que Isaac, por meio da linguagem corporal, preferiria estar em um local mais seguro. Os monstros, que ele enfrenta durante o jogo, estão dispostos hierarquicamente mais acima e ao redor dele, cercando-o. A modalidade, responsável pelos diferentes graus de realidade, ocorre, assim como no decorrer do jogo, sob a forma de desenho, o que faz com que se tenha um distanciamento da realidade dos pavores enfrentados por Isaac. Também é possível observar os atributos que definem a personagem principal, como as lágrimas em seus olhos, sua nudez e suas formas bastante arredondadas. A ausência das roupas da personagem pode ser um fator que contribui para a sua posição fetal, como forma de cobrir-se, além de remeter diretamente à violência intrafamiliar por ele sofrida, já que sua mãe foi quem as tirou e o relegou a essa situação degradante.

\footnotetext{
${ }^{8}$ Gameplay, segundo Souza (2014), é todo o conjunto de ações a serem realizadas pelo jogador, estando elas voltadas a objetivos, desafios, estratégias, escolhas, decisões, ações, regras e consequências.
} 
De acordo com Kress e Van Leeuwen (2006, p. 86), participantes representados por formas circulares ou ovais, diferentemente daqueles representados por formas retangulares, aproximam-se mais do que é natural e orgânico. Além disso, durante uma partida, por exemplo, percebe-se pequenos desenhos, também arredondados, feitos no chão do porão a lápis. Os próprios comandos iniciais que mostram como controlar Isaac são, da mesma forma, desenhados no chão, como pode ser visto na figura 2. As formas arredondadas, assim, possuem a função de estabelecer empatia com o jogador, que, apesar de saber que é apenas um jogo, simpatiza com sua personagem.

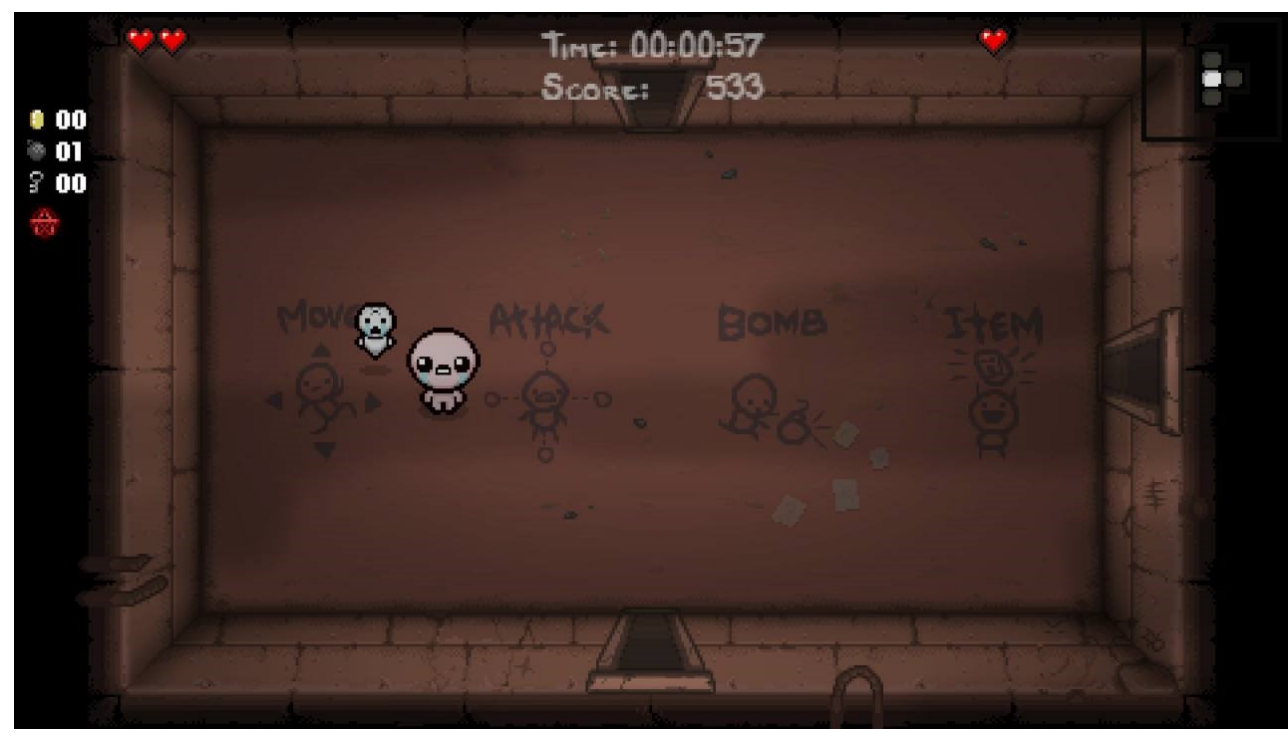

\section{Figura 2 - Sala inicial do jogo}

Fonte: https://blog.bestbuy.ca/wp-content/uploads/2017/04/The-Binding-of-Isaac-Afterbirth-7-450x253.jpg

Após a apresentação do contexto de situação do jogo, suas práticas discursivas mais relevantes foram compiladas, reveladas por meio da intercontextualidade presente nos nomes e formas visuais de itens que a personagem principal adquire ao longo da partida, os quais a tornam mais forte, assim como os nomes e as formas visuais de alguns monstros.

A primeira prática discursiva verificada refere-se a itens que dividem intercontextualidade com as tecnologias da informação e comunicação, como os itens Technology, Technology 2, Technology 5 e Tech X, que emitem raios ao invés de tiros de lágrimas, e o item Missing No. (Número ausente), uma alusão às falhas que ocorrem em sistema digitais, que faz com que os itens a serem obtidos por Isaac sejam trocados por outros.

O discurso que envolve mídias audiovisuais também se faz presente, como nos itens The Clicker, um controle remoto que faz com que o jogador possa trocar de personagem, e The Ludovico Technique, cuja forma lembra garras metálicas presas a um olho, uma alusão direta ao filme Laranja Mecânica (1972), no qual a personagem Alex participa de um experimento fictício chamado Técnica Ludovico. 
Além da intertextualidade conceitual compartilhada com o jogo The Legend of Zelda (1986), conforme mostra a figura 3, a seguir, o jogo também se vale da intertextualidade com outros jogos clássicos. O item The Gamekid, cujo subtítulo é Temporary pac-man, transforma Isaac temporariamente em um monstro colorido semelhante à personagem principal do clássico jogo Pac-man (1980). Os itens How to jump (Como pular), que faz com que Isaac ganhe a habilidade de pular; Magic mushroom (Cogumelo mágico), um cogumelo vermelho gigante que faz com que ele cresça; e lup! (Uma vida a mais), que dá a Isaac uma vida extra, são exemplos de uma óbvia intertextualidade, quer seja visual ou verbal, com os jogos da série Mario Bros (1983). O item BomberBoy, que dá a Isaac cinco bombas a mais, é uma referência direta ao clássico jogo Bomberman (1983), assim como o inimigo Wrath (Ira), uma cópia quase que ipsis litteris do visual da personagem principal do jogo. Os itens Poke go, que faz com que surja um inimigo domesticado que destrói outros inimigos, e Friendly ball, que permite que inimigos sejam presos em uma bola e posteriormente soltos, são uma clara alusão aos jogos da série Pokemon (1996). Finalmente, o item Mine crafter, que faz com que surja um barril que pode ser explodido, é uma referência direta ao famoso jogo Minecraft (2011), cuja principal característica é a criação de objetos.

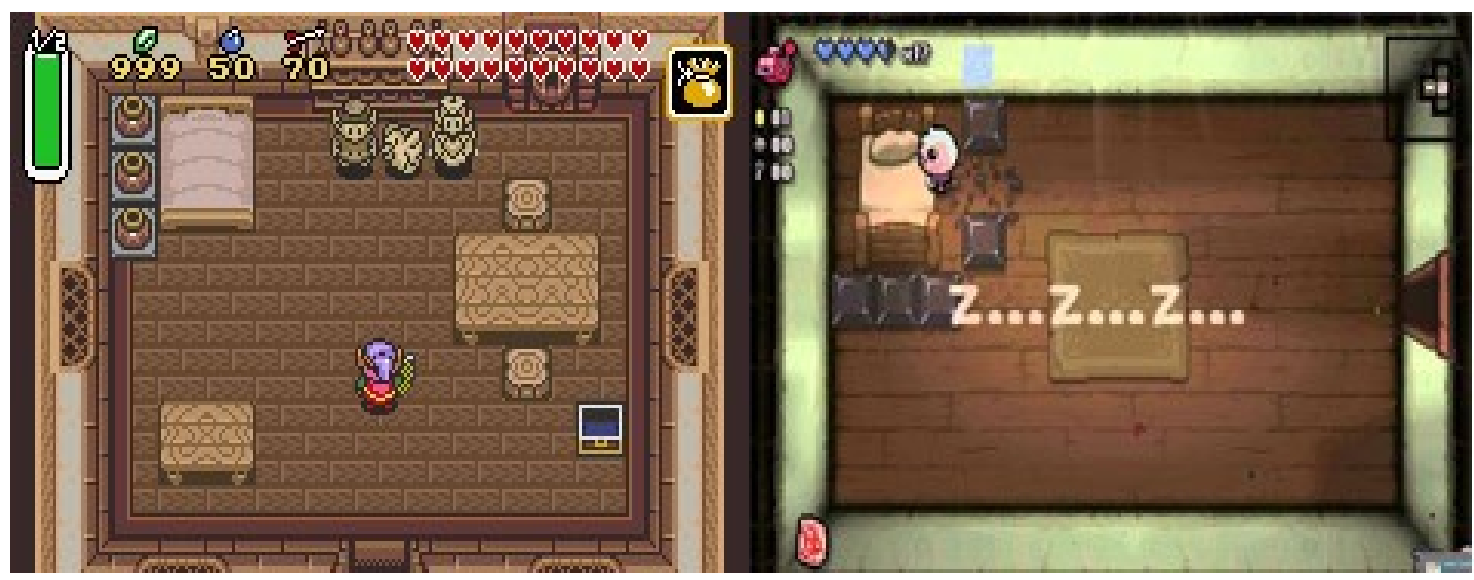

Figura 3 - The Legend of Zelda (1983) e The Binding of Isaac (2011)

Fonte: Figura criada a partir da colagem de duas imagens. A imagem da esquerda corresponde ao jogo The Legend of Zelda (1983) e a segunda imagem corresponde ao jogo The Binding of Isaac (2011). As imagens foram obtidas em: https://gamepedia.cursecdn.com/zelda_gamepedia_en/c/c3/Woodcarvings.png?version=ab46bdd6ffc90448f0e8cf459 b0d41e0 e https://i.ytimg.com/vi/LYO2AqhfWUo/maxresdefault.jpg, respectivamente.

Por ser um jogo do tipo masmorra, o discurso da aleatoriedade, voltado à superstição e ao misticismo, está presente de várias maneiras, como em itens que possuem a forma de cartas de tarô disponíveis ao longo do jogo, a exemplo da carta do hierofante, que dá a Isaac dois corações azuis; a carta dos amantes, que concede dois corações vermelhos; ou a carta do enforcado, que faz com que Isaac tenha a cabeça separada do corpo e possa flutuar. Há também itens que representam dados de quatro, seis e 20 lados, comuns em jogos físicos de RPG, em que o resultado numérico permite ou impede um jogador de realizar uma ação. No jogo, eles têm a capacidade de modificar inimigos, itens e poderes. Os itens Dead cat (Gato morto), que concede a Isaac nove vidas extras; e Lucky foot (Pé da sorte), um chaveiro com um pé humano ao invés do célebre pé de coelho, são 
referências diretas às superstições populares. Além disso, os signos do zodíaco também estão presentes em itens como Aries, que faz com que Isaac obtenha mais velocidade; Gemini, no qual um monstrinho raivoso se atrela à cabeça de Isaac por meio de um cordão umbilical; ou Leo, que faz com que Isaac obtenha uma juba de leão e possa destruir rochas.

Uma outra prática discursiva relevante é a que se manifesta por meio de itens voltados à biologia, como E.coli (Escherichia Coli), uma referência à bactéria encontrada em intestinos humanos, fazendo com que todos os seus inimigos virem cocô; The common cold (O resfriado comum), um item com a forma de uma massa de catarro que faz com que Isaac mate seus inimigos por envenenamento; Glaucoma, que faz com que os inimigos de Isaac, ao serem atingidos, não o persigam mais; Stem cells (Células tronco), que presenteia Isaac com um coração a mais; Magic Scab, uma casca de ferida mágica que aumenta a probabilidade de surgirem melhores itens ${ }^{9}$; Kidney Stone (Pedra no rim) que faz com que Isaac solte tiros mais potentes juntamente com os tiros habituais; e $D r$. Fetus $^{10}$, um item com a forma de um feto usando monóculo dentro de um pote de vidro, que faz com que Isaac jogue bombas ao invés de tiros de lágrimas. Além disso, há também pílulas que Isaac encontra ao longo do jogo, como as pílulas Amnesia, que impede a visualização do mapa das salas; Paralysis, que faz com que Isaac fique paralisado por alguns segundos; Bad Trip ${ }^{11}$ (Viagem ruim), que faz com que Isaac perca um coração, ou Explosive diarrhea, que faz com ele solte uma sequência simultânea de bombas.

$\mathrm{O}$ discurso sobre suicídio pode ser percebido no efeito que alguns itens possuem, como Plan c (Plano c), que mata todos os inimigos na sala, incluindo Isaac; Fate (Destino), com a forma de uma cabeça morta que faz com que Isaac tenha a habilidade de voar; Guillotine, que faz com que a cabeça de Isaac seja separada do corpo; Transcendence, cujo ícone possui a forma de uma corda de forca que faz com que Isaac também voe; e Kamikaze!, um item com o formato de bombas atreladas a um relógio que, ao ser acionado, faz com que todos os inimigos sejam mortos e Isaac perca vários corações.

De fato, a intercontextualidade com o discurso religioso é uma das mais presentes no jogo. Há vários livros e bíblias, como The book of revelations (o livro das revelações), que concede corações azuis; The book of secrets (o livro dos segredos), que mostra salas secretas no mapa, The book of Shadows (o livro das sombras), que dá a Isaac invencibilidade temporária; The book of Sins (o livro dos pecados), que faz com que itens aleatórios apareçam, The bible (a bíblia), que faz com que Isaac possa voar temporariamente; The satanic bible (a bíblia satânica), que concede corações pretos; ou o Necronomicon, famoso livro fictício de bruxarias criado pelo escritor H. P. Lovecraft, que dá a Isaac força para matar todos os inimigos de uma só vez.

\footnotetext{
${ }^{9}$ Este item também está voltado ao discurso da aleatoriedade, já que aumenta a probabilidade de itens melhores surgirem. De fato, por ser um jogo baseado na aleatoriedade, todos os itens que surgem no jogo podem ser compreendidos a partir desse discurso.

${ }^{10}$ Este item em particular é uma referência direta ao inimigo do jogo Super Meatboy (2010), desenvolvido pelos mesmos produtores de The Binding of Isaac (2011).

${ }^{11}$ Este item também traz uma referência direta ao termo usado para descrever o efeito desagradável de drogas ilícitas, como a heroína e o LSD.
}

RODRIGUES, Johwyson da Silva. Violência intrafamiliar contra crianças e adolescentes: intercontextualidade de significados verbais e imagéticos. Linguagem em (Dis)curso - LemD, Tubarão, SC, v. 20, n. 3, p. 431-450, set./dez. 2020. 
Há itens claramente inspirados no cristianismo, como Habit, com a forma de um hábito de freira; Blood of the martyr (Sangue do mártir), que se assemelha a uma coroa de espinhos; Ceremonial robe (Manto cerimonial), que faz com que Isaac ganhe três corações negros; e os itens Holy Grail (Santo Graal), Holy mantle (Manto sagrado) e Holy water (Água benta), que dão proteção e força à Isaac, assim como o item Mitre, um tipo de coroa comum no catolicismo, utilizada por líderes religiosos.

Já outros itens fazem referência ao discurso satânico, como Ouija board (Tábua de Ouija), que faz com que Isaac seja capaz de lançar tiros que atravessam rochas; The pact (O pacto), cujo ícone lembra a forma de um documento manchado de sangue; ou Goat head (Cabeça de bode), que faz com que a probabilidade de salas demoníacas e salas do anjo apareçam, uma clara alusão a um pacto satânico em prol de um benefício, já que essas salas geralmente contêm itens poderosos.

Dentre alguns inimigos enfrentados por Isaac, estão monstros cujos nomes remetem aos sete pecados capitais, Envy (Inveja), Gluttony (Gula), Wrath (Ira), Pride (Soberba), Lust (Luxúria), Greed (Avareza) e Sloth (Preguiça); aos anjos Uriel e Gabriel; inimigos que aludem à figura do diabo, como The dark one (o obscuro), The adversary (o adversário), The fallen (o caído), Big Horn (Chifre grande) e Little Horn (Chifre pequeno); aos quatro cavaleiros do apocalipse: Death (Morte), War (Guerra), Pestilence (Peste) e Famine (Fome); e inimigos que se valem da referência direta com o diabo, como Satan e Mega Satan.

O discurso sobre o cotidiano familiar presente no jogo pode funcionar como uma categoria maior que abriga outras intercontextualidades, como a que envolve o discurso da sexualidade, revelado por itens que dão mais poder a Isaac, como Mom's Pearls (Colar de pérolas da mãe), Mom's heels (Salto alto da mãe), Mom's lipstick (Batom da mãe), Mom's underwear (Roupas íntimas da mãe), Mom's perfume (Perfume da mãe), Mom's wig (Peruca da mãe) e Mr. Dolly (Senhor boneca), que, apesar de incluir o pronome de tratamento mister, tem a forma de uma boneca, comumente tida como um brinquedo de meninas. Ao apanhar esses itens de vestimenta, Isaac literalmente traveste-se com eles. $\mathrm{O}$ fato desses itens tornarem Isaac mais forte talvez esteja relacionado ao seu empoderamento e à sua liberdade identitário-sexual. O item Fruit cake (bolo de frutas), por exemplo, que remete ao termo anglófono pejorativo para gays, referindo-se, aqui, ao discurso de bullying, faz com que Isaac fique mais forte ao lançar tiros de efeito randómico, assim como itens que remetem ao símbolo do arco-íris, como Rainbow tears (Lágrimas de arco-íris), Rainbow effects (Efeitos de arco-íris) e Rainbow Baby (Bebê arco-íris).

Algumas imagens contendo um tipo de discurso que envolve o bullying também podem ser percebidas nos cutscenes que ocorrem entre as fases do jogo. Na figura 4, a seguir, é possível ver, na imagem à esquerda, crianças defecando em Isaac, enquanto, na imagem à direita, uma criança ri de Isaac por ele estar usando uma peruca. É importante destacar que esses cutscenes são realizados por meio de processos mentais, ressaltando, de forma psicológica, as lembranças que Isaac guarda de situações sociais. 

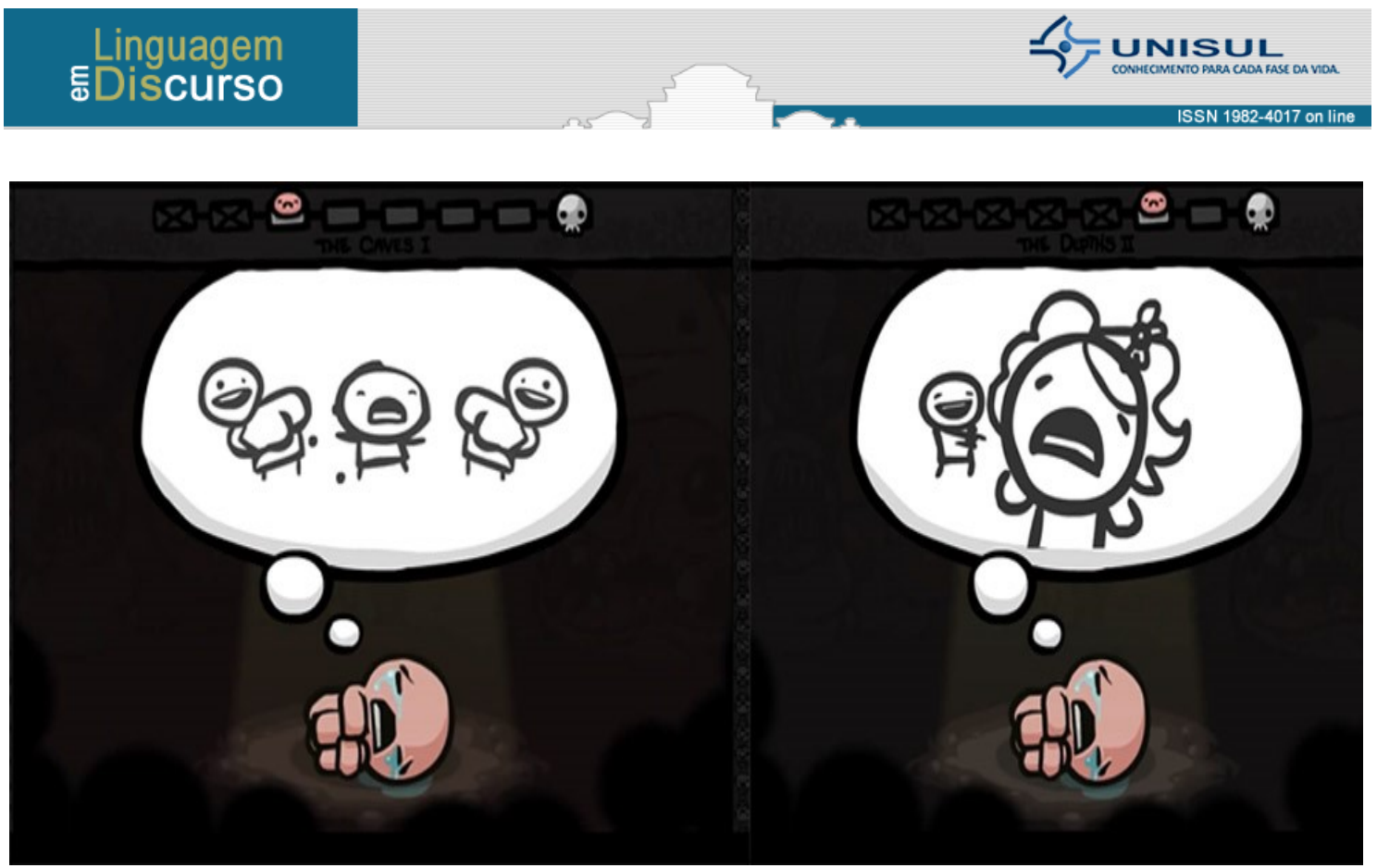

\section{Figura 4 - Bullying em cutscenes}

Fonte: Colagem de dois cutscenes que ocorrem entre as fases, feita a partir da captura de imagens durante um gameplay.

O discurso que revela a mãe de Isaac como uma figura perturbada e repressora pode ser percebido nos itens Wooden spoon (Colher de pau) e Belt (Cinto), que fazem com que Isaac ganhe mais velocidade. Com base no efeito desses itens, pode-se inferir que sua mãe geralmente os utiliza para repreendê-lo e que é preciso, então, correr. O item Mom's Bra (Sutiã da mãe) que, quando acionado, faz com que apareça a figura de uma mulher repulsiva usando um sutiã, permite que todos os inimigos da sala tenham medo de Isaac. Outros itens também estão relacionados à mãe de Isaac e, consequentemente, podem ser compreendidos como seus atributos identitários, como Mom's knife (Faca da mãe), Mom's shovel (Pá da mãe), Mom's eyeshadow (Delineador da mãe), Mom's key (Chave da mãe) e Mom's bottle of pills (Frasco de pílulas da mãe), um dispensador de pílulas com efeito randômico. Além disso, os monstros Mom, uma perna gigante de salto alto, e Mom 's Heart, um coração gigante que solta tiros, Mom's hand (Mão da mãe) e Mom's dead hand (Mão morta da mãe) são referências diretas à mãe de Isaac que reafirmam quão demoníaca é a sua representação.

Alguns cutscenes que ocorrem entre as fases do jogo também representam a mãe de Isaac praticando atos explícitos de violência intrafamiliar. $\mathrm{Na}$ figura 5, a seguir, em que são destacadas duas imagens realizadas por processos mentais, percebe-se, nas imagens acima, que a sua mãe o presenteia com fezes. Nas imagens abaixo, pode-se ver Isaac sendo afastado ao tentar abraçá-la. 

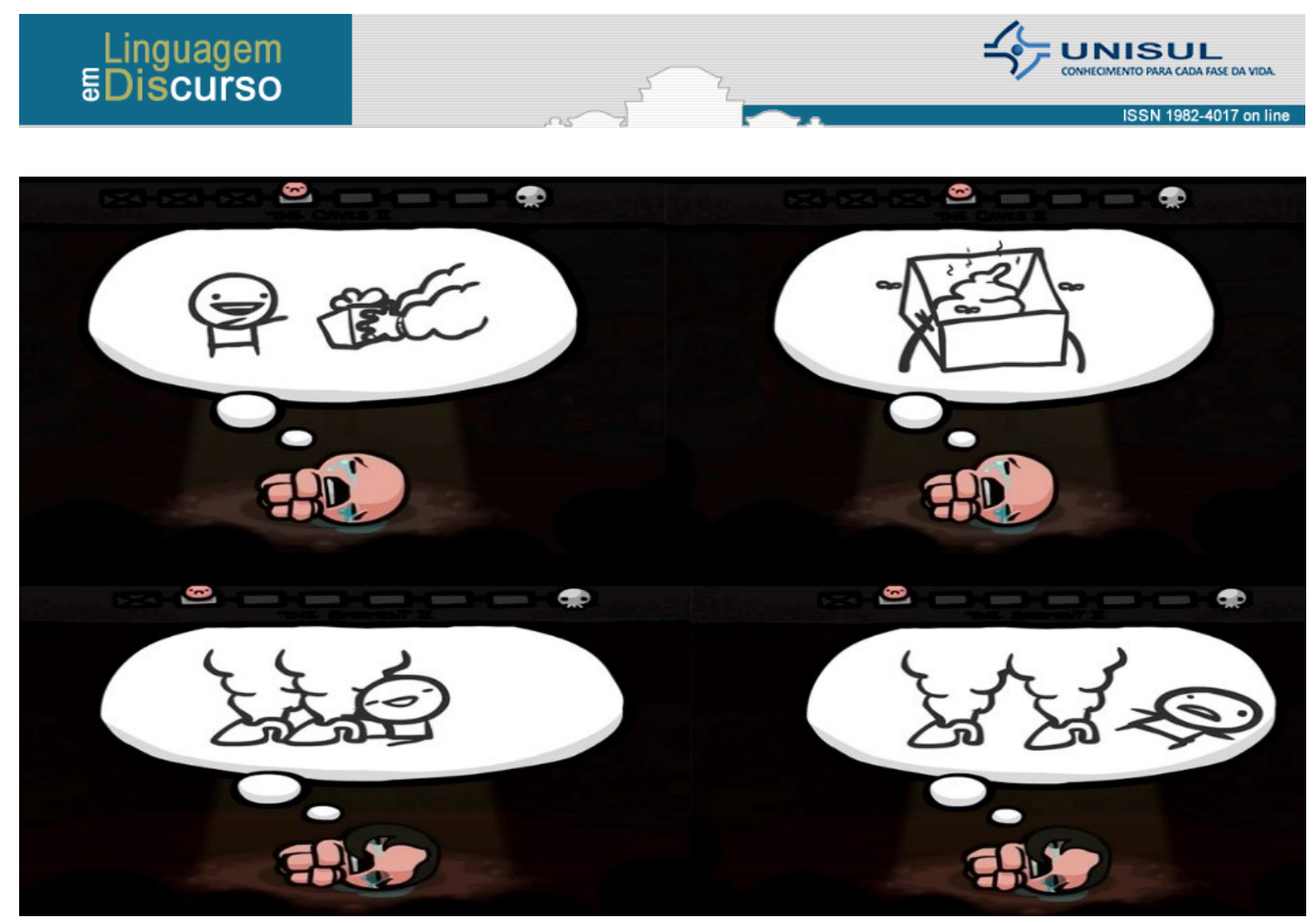

Figura 5 - Violência praticada pela mãe em cutscenes

Fonte: Colagem de dois cutscenes que ocorrem entre as fases, feita a partir da captura de imagens durante um gameplay.

O discurso paterno também pode ser percebido por meio de itens como Dad's lost coin (Moeda perdida do pai) ou Dad's ring (Aliança do pai). No entanto, os itens que provavelmente parecem revelar mais sobre o pai de Isaac são Daddy longlegs (Pernas longas do pai), uma perna esquelética que pisa sobre os inimigos de Isaac, e Torn photo (Foto rasgada), um item com a forma de uma fotografia em que Isaac aparece com a mãe, pressupondo-se, pela forma com que as pessoas estão dispostas, que o pai estava presente na parte rasgada da foto. O item Divorce papers (Papéis do divórcio) parece afirmar não apenas o discurso paterno, mas também o discurso do pai ausente, já que o pai de Isaac não aparece no cutscene inicial como membro da família. O item The polaroid, com o formato de uma antiga fotografia em que Isaac aparece com seu pai e mãe, faz com que, dentre outros benefícios, os danos sofridos por inimigos sejam menores.

Finalmente, um discurso rotulado aqui como costumes e crendices infantis, parece revelar mais facetas identitárias de Isaac. Os itens Guppy's head, Tammy's head, Rob's rotten head e Kricket's head, que se assemelham a cabeças de animais que tornam Isaac mais forte, parecem remeter ao discurso da perda de animais de estimação na infância. $\mathrm{O}$ discurso que envolve o cotidiano infantil também pode ser notado no item Ipecac, uma alusão ao xarope de ipeca, comumente utilizado no passado como expectorante. Os itens Butter bean (Feijão manteiga), The bean (O feijão), Mega bean (Mega feijão) e Black bean (Feijão preto) fazem com que Isaac emita gases que matam seus inimigos, uma alusão à flatulência causada pela ingestão de feijões. A lump of coal (Um punhado de carvão), com o subtítulo, My xmas presente (Meu presente de natal), faz referência à crendice norte-americana de que crianças que não se comportaram durante o ano ganham um pedaço de carvão de Papai Noel no natal. O item Apple!, uma maçã com uma lâmina encravada, com o subtítulo Trick or treat (Gostosuras ou travessuras), uma referência ao 
Halloween, faz com que Isaac atire lágrimas vermelhas e dentes. $P J_{S}$, com a forma de um pijama de bebê, que pode ser interpretado como alusão a um passado feliz, faz com que Isaac diminua de tamanho e obtenha quatro corações azuis. Pageant boy, menção aos concursos de beleza para crianças, faz com que várias moedas apareçam. The Wiz, um chapéu coniforme escrito dunce (burro), faz referência a um antigo método punitivo utilizado em escolas. O item My reflection, com a aparência de um espelho quebrado que faz com que os tiros de Isaac ricocheteiem, e o vilão Isaac, cuja aparência é idêntica à da personagem Isaac, são exemplos de um tipo de discurso que envolve a autoaceitação da imagem e talvez estejam relacionados aos medos e construções identitárias criados por Isaac, os quais precisam ser enfrentados para que ele saia da situação em que se encontra.

Por meio dos cutscenes e de outros recursos verbais e visuais realizados pelo jogo, pode-se confirmar que a mãe de Isaac é, sem dúvida, a agente da violência intrafamiliar sofrida por ele, a qual realiza, com base em Garbarino et al (1986), pelo menos quatro das cinco ações parentais consideradas tóxicas: rejeitar, quando esta impede Isaac de abraçá-la, privando-o de necessidades emocionais; ignorar, quando esta retira todos os seus brinquedos e roupas, privando-o de estímulos; isolar, ao trancá-lo em seu quarto, impedindo-o de ter contato com o mundo exterior; e, como consequência, estimulando-o a corromper-se com comportamentos negativos e antissociais. Pode-se ainda afirmar que o tipo de violência praticada pela mãe é tanto de ordem psicológica, quanto física, uma vez que ela também o persegue com uma faca.

No momento em que Isaac entra no porão, os itens e inimigos a serem obtidos/enfrentados por ele, traços claros de intercontextualidades que revelam práticas discursivas diversas, podem ser compreendidos como consequências da ação parental de aterrorizar, já que, coincidentemente, esses elementos, pertencentes ao seu conhecimento de mundo, possuem uma nítida relação com fatos e experiências por ele vividos. Dentre algumas experiências consideradas positivas e estimulantes, por exemplo, estão a sua relação com as tecnologias de informação e comunicação, com a mídias audiovisuais e com os jogos digitais, que surgem sob a forma de itens poderosos que o auxiliam a derrotar inimigos. Esses itens podem ser encarados como os estímulos e as motivações que possibilitam o seu desenvolvimento infantil. $\mathrm{O}$ desenvolvimento da sua sexualidade, percebida por itens obtidos ao longo do jogo, possui a função de empoderar Isaac. A aleatoriedade surge como a ideologia popular de que somos controlados por forças superiores, como os signos do zodíaco, os jogos de azar ou os amuletos da sorte, que protegem as pessoas conta mau agouros e trazem sorte.

Os itens que atestam os comportamentos negativos e antissociais percebidos em Isaac, resultado da violência intrafamiliar realizada por sua mãe, revelam-se por meio dos terrores provocados por ideologias voltadas à religião, sob a forma dos itens e monstros aqui elencados, e à Biologia, como doenças, parasitas e o efeito de certos medicamentos. O suicídio, normalmente tido como uma possível saída de uma situação da qual não se pode escapar, surge como meio de transcender a forma física ou simplesmente subtraí-la, já que os itens que o representam fazem com que Isaac possa voar, causam danos ou até mesmo a sua morte. Os terrores psicológicos provocados pela mãe de Isaac também repercutem na forma com que ele lida com sua autoimagem, com hábitos de sua infância, percebidos pela forma com a qual ele lida com o bullying, com a ausência paterna, com certas crenças populares e datas comemorativas comuns à infância. 
Os cutscenes finais do jogo, ao contrário de jogos em que os vilões são vencidos, são extremamente pessimistas. A maioria deles envolve um baú, em que Isaac encontra itens como uma forca e, logo em seguida, suicida-se; em que a mão de sua mãe o puxa para dentro do baú; ou em que sua mãe, ao abrir o baú, encontra a ossada de Isaac, inferindo que ele já tenha morrido há muito tempo. Alguns deles mostram Isaac assumindo a forma de um demônio, a personagem Azazel, e outros apresentam cartazes em que ele é tido como desaparecido. Todos esses finais levam o jogador a crer que Isaac, apesar de derrotar seus inimigos, não conseguiu livrar-se da situação nefasta em que se encontrava. Também leva o jogador a inferir que todo o gameplay pode tratar-se apenas de fantasias vividas por ele enquanto está preso no porão à espera da morte.

\section{CONSIDERAÇÕES FINAIS}

Por meio deste estudo, que teve como objetivo investigar traços da VICCA no jogo digital The Binding of Isaac (2011), utilizando a ACD e a GDV como aporte teóricometodológico, pode-se verificar que as estruturas multimodais revelaram práticas discursivas, como as relacionadas às tecnologias de informação e comunicação, às mídias audiovisuais, a outros jogos digitais, à aleatoriedade, à biologia, ao tema do suicídio, à religiosidade e aos vários discursos de cunho familiar, os quais envolvem sexualidade, bullying, opressão materna, ausência paterna, costumes e crendices na infância. Por meio da verificação desses discursos, com base em Garbarino et al. (1986), a pesquisa foi capaz de identificar traços consistentes relativos à VICCA como prática social representada no jogo The Binding of Isaac (2011). A análise realizada também possibilitou a verificação dos atributos que constroem a personagem Isaac, os quais, por conta da agressão sofrida, manifestam-se psicologicamente de forma distorcida, fruto de convencimentos incutidos por sua mãe. Esses convencimentos, carregados de ideologias, são eficazes na manutenção da relação de poder mantida entre Isaac e sua mãe, fazendo com que ele seja refém das suas vontades e violência.

A escolha pela inserção do tema da VICCA no jogo The Binding of Isaac (2011) não poderia ter sido mais assertiva, uma vez que, sendo um veículo não apenas de entretenimento, mas também de comunicação, os jogos digitais podem fazer com que seus jogadores tenham a chance de refletir sobre suas próprias posições discursivas com relação a comportamentos sociais, os quais, por também serem de cunho ideológico, parecem pairar sobre nosso cotidiano de forma naturalizada. Nesse sentido, o jogo serve de alerta e de introdução ao tema da VICCA, o qual ainda precisa ser mais profundamente discutido e abordado em ambientes sociais como o familiar, o escolar, etc.

Por fim, a exemplo de trabalhos como os de Heberle (2016, 2018), aqui citados, corrobora-se a eficácia da união entre a ACD e a GDV na investigação de significados verbais e visuais, os quais, por meio do texto, podem revelar discursos e ideologias despercebidas em nossas práticas cotidianas. 
ABRANCHES, C. D.; ASSIS, S. G. A (in)visibilidade da violência psicológica na infância e adolescência no contexto familiar. Cadernos de Saúde Pública (ENSP. Impresso), v. 27, p. 843-854, 2011.

BRASIL. Constituição da República Federativa do Brasil: promulgada em 5 de outubro de 1988.

BRASIL. Estatuto da criança e do adolescente: Lei federal nº 8069, de 13 de julho de 1990. Rio de Janeiro: Imprensa Oficial, 2002.

BRASSARD, M. R.; HART, S. N.; HARDY, D. B. The psychological maltreatment rating scales. Child Abuse \& Neglect, n. 6, v. 17, 1993, p. 715-729.

CAMPOS, J. G. S.; BARROS, D. E. C. Estados paradoxais das ordens do ver e do dizer: a identidade da mulher brasileira em uma propaganda institucional de homenagem ao dia internacional da mulher.

Linguagem em (Dis)curso, Tubarão, v. 14, n. 1, p. 159-176, jan./abr. 2014.

CHOULIARAKI, L.; FAIRCLOUGH, N. Discourse in late modernity: rethinking Critical Discourse Analysis. Edinbourg: Edinbourg University, 1999.

Dias, L. S.; A. M. "Do you need to know the person to donate?" facework strategies in Brazilian blood donation campaigns: a multimodal analysis. Linguagem em (Dis)curso, Tubarão, SC, v. 16, n. 3, p. 401419, set./dez. 2016.

EGENFELDT-NIELSEM, S.; SMITH, J.H.; TOSCA, S. P. Understanding videogames: the essential introduction. Nova Iorque e Londres: Routledge, 2008.

FAIRCLOUGH, N. Analysing discourse: textual analysis for social research. London: Routledge, 2003. FAIRCLOUGH, N. Critical discourse analysis: the critical study of language. $2^{\text {nd }}$ ed. Londres e Nova Iorque: Routledge, 2010.

FAIRCLOUGH, N. Análise crítica do discurso como método em pesquisa social científica. Tradução de Iran Ferreira de Melo. Linha d'Água, n. 25, v. 2, p. 307-329, 2012.

FUZER, C.; CABRAL, S. R. S. Introdução à Gramática Sistêmico-Funcional em língua portuguesa. Campinas, SP: Mercado de Letras, 2014.

GARBARINO J.; GUTTAMANN, E.; SEELEY, J. W. The psychologically battery child. San Francisco: Jossey-Bass Publishers, 1986.

HAAG, C. R.; FRAGA, D.; SILVA, L. C.; LACERDA, Giovane Dantas. O jogo digital como um "hipergênero". Revista Letra Magna, São Paulo, v. 2, n. 3, p. 1-13, 2005.

HALLIDAY, M.A.K; HASAN, R. Language, context, and text: aspects of language in a social-semiotic perspective. Oxford: Oxford University Press, 1989.

HALLIDAY, M. A. K. An Introduction to Functional Grammar. 2. ed. London: Edward Arnold, 1994.

HALLIDAY, M. A. K.; MATTHIESSEN, C. M. I. M. An introduction to functional grammar. 3. ed. Londres: Arnold, 2004.

HALLIDAY, M. A. K.; MATTHIESSEN, C. M. I. M. Halliday's introduction to functional grammar. 4. ed. London: Arnold, 2014.

HEBERLE, V. M.; MORGADO, M. Discussing the representation of immigrants: An integrated view from SFL, CDA and Multimodality. International Journal of Language Studies, Raleigh, CN, v. 10, n. 2, p. $57-78,2016$.

HEBERLE, V. M. Apontamentos sobre linguística sistêmico-funcional, contexto de situação e transitividade com exemplos de livros de literatura infantil. DELTA, São Paulo, v. 34, n. 1, p. 81-112, 2018.

LEAL, A. A. Representações semióticas no gênero reportagem em revistas portuguesas. Linguagem em (Dis)curso, Tubarão, SC, v. 18, n. 2, p. 341-357, maio/ago. 2018.

OTERO, J. The Binding of Isaac Afterbirth+ Review. Mar. 2017. Disponível em:

https://www.ign.com/articles/2017/03/17/the-binding-of-isaac-afterbirth-review. Acesso em: 22 mar. 2019.

MAINGUENEAU, D. Hipergênero, gênero e internet. In: MAINGUENEAU, D. (Org.). Doze conceitos em Análise do Discurso. São Paulo: Parábola Editorial, 2010. p. 129-138.

MEURER, J. L. Gêneros textuais na análise crítica de Fairclough. In: MEURER, J. L.; BONINI, A.; MOTTA-ROTH, D. (Org). Gêneros: teorias, métodos, debates. 2. ed. São Paulo: Parábola Editorial, 2007. p. 81-106.

MEURER, J. L. Ampliando a noção de contexto na lingüística sistêmico-funcional e na análise crítica do discurso. Linguagem em (Dis)curso - LemD, Tubarão, v. 4, n. esp, p. 133-157, 2004.

RODRIGUES, Johwyson da Silva. Violência intrafamiliar contra crianças e adolescentes: intercontextualidade de significados verbais e imagéticos. Linguagem em (Dis)curso - LemD, Tubarão, SC, v. 20, n. 3, p. 431-450, set./dez. 2020. 
MORALIS, R. L. G. L.; RODRIGUES, V. P.; MACHADO, J. C.; ROCHA, E. N.; VILELA, A. B. A.; SALES, Z. N. Violência intrafamiliar contra crianças no contexto da saúde da família. Rev. Enferm. UFPE, Recife, n. 10, v. 5, p. 1645-53, 2016.

O'HAGAN, K. P. Emotional and psychological abuse: problems of definition. Child Abuse \& Neglect, n. 4, v. 19, 1995, p. 449-461.

OLIVEIRA, K. C.; PIMENTA, S. M. O. O racismo nos anúncios de emprego do século XX. Linguagem em (Dis)curso, Tubarão, SC, v. 16, n. 3, p. 381-399, set./dez. 2016.

RAMALHO, V.; RESENDE, V. M. Análise de discurso (para a) crítica: O texto como material de pesquisa. São Paulo: Pontes Editores, 2011.

RAMOS, M. L. C. O.; SILVA, A. L. Estudo sobre a violência doméstica contra a criança em unidades básicas de saúde do município de São Paulo - Brasil. Saúde e Sociedade (USP. Impresso), v. 20, p. 136146,2011

REZENDE, B. R. M. P. R. Hipergênero e sistema de hipergenericidade: análise do funcionamento discursivo do Facebook. 2018. 69f. Dissertação (Mestrado em Estudos Linguísticos) - Programa de Pósgraduação em Estudos Linguísticos, Universidade Federal de Uberlândia, Uberlândia, 2018.

RESENDE, V. M.; GOMES, M. C. A. Representação da situação de rua no jornalismo eletrônico em textos verbo-visuais - a violência em discurso no Correio Braziliense (2011-2013). Linguagem em (Dis)curso, Tubarão, SC, v. 18, n. 1, p. 165-191, jan./abr. 2018.

ROGUELIKE. In: Wikipédia: a enciclopédia livre. Disponível em: < https://pt.wikipedia.org/wiki/Roguelike > Acesso em: 5 jun. 2020.

SILVA, E. R.; GONCALVES, C. A. Possibilidades de incorporação da análise crítica do discurso de Norman Fairclough no estudo das organizações. Cadernos EBAPE.BR (FGV), v. 15, p. 1-20, 2017.

SOUZA, R. V. F. O conceito de "gameplay experience" aplicado à localização de games. In: ALTHOFF, G. Dossiê - Localização de games: um olhar interdisciplinar. Scientia Traductionis. Florianópolis, Santa Catarina, v. 15, 2014.

\section{JOGOS, MÍDIAS E SITES CITADOS}

BOMBERMAN. Japão: Hudson Soft, 1983. Arcade, NES.

GAMEPEDIA. The binding of Isaac Rebirth Wiki. 2019. Disponível em:

https://bindingofisaacrebirth.gamepedia.com/Binding_of_Isaac:_Rebirth_Wiki. Acesso em: 05 fev. 2019. LARANJA Mecânica. Reino Unido: Colúmbia-Warner, 1972. TV, TV a cabo, Streaming.

MARIO Bros. Japão: Nintendo, 1983. NES

MINECRAFT. Mojang AB, 2011. PC, Mac OS, Linux, Nintendo Switch, PS4, Xbox one.

PAC-MAN. Japão: Namco, 1980. Arcade, NES, Atari.

POKEMON. Japão: Nintendo, 1996. Game Boy.

SUPER Meatboy. EUA: Team Meat, 2010. PC.

THE BINDING of Isaac. EUA: Edmund McMillen e Headup Games, 2011. PC, MacOS, Linux.

THE BINDING of Isaac: Rebirth. EUA: Edmund McMillen e Headup Games, 2014. PC, MacOS, Linux, PS4, Xbox one, Nintendo Switch.

THE BINDING of Isaac: Afterbirth. EUA: Edmund McMillen e Headup Games, 2015. PC, MacOS, Linux, PS4, Xbox one, Nintendo Switch.

THE BINDING of Isaac: Afterbirth +. EUA: Edmund McMillen e Headup Games, 2017. PC, MacOS, Linux, PS4, Xbox one, Nintendo Switch.

THE BINDING of Isaac: Four Souls. EUA: Edmund McMillen e Kickstarter, 2018. Tabuleiro.

THE LEGEND of Zelda. Japão: Nintendo, 1986. NES.

TOMB Raider. EUA: Eidos Interactive, 1996. PS1.

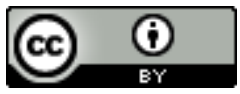

Este texto está licenciado com uma Licença Creative Commons Atribuição 4.0 Internacional.

RODRIGUES, Johwyson da Silva. Violência intrafamiliar contra crianças e adolescentes: intercontextualidade de significados verbais e imagéticos. Linguagem em (Dis)curso - LemD, Tubarão, SC, v. 20, n. 3, p. 431-450, set./dez. 2020. 